\title{
CHANNELIZATION STRATEGIES OF RADICALISM AMONG MUSLIM UNIVERSITY STUDENTS IN INDONESIA
}

\author{
Rahma Sugihartati | Universitas Airlangga - Indonesia \\ Bagong Suyanto | Universitas Airlangga - Indonesia \\ Medhy Aginta Hidayat | Universitas Trunojoyo Madura - Indonesia \\ Corresponding author: rsugihartati@yahoo.com
}

\begin{abstract}
This article examines the channelization of radicalism by fundamentalist-religious organizations among Muslim university students in Indonesia. The data are taken from 700 Muslim students' respondents in seven Indonesian universities. This study finds that the channelization of radicalreligious ideology in Indonesia takes place via new media with three layers of channels: open-public channel, restricted-public channel, and private channel. The first channel, which is relatively public and overt media platforms, is used to communicate and launch their messages, as well as to expand their ideological propaganda. The second channel, which includes some public but relatively closed media platforms, is used by radical-religious organizations in Indonesia to recruit their new members. By the third channel, a more closed and private media platform becomes the final channel to select new cadres. This research finding is expected to be a complementary reference for the de-radicalization processes that are disseminated via new media to young Muslims and university students in Indonesia.
\end{abstract}

Keywords: Channelization strategy, Muslim university students, radicalism, new media.

\section{Introduction}

Since the last two decades, radical Islamist groups in Indonesia have begun to target young people and university students by utilizing new media technologies. ${ }^{1}$ These new media platforms, especially social

\footnotetext{
${ }^{1}$ Birgit Bräuchler, "Islamic Radicalism Online: The Moluccan Mission of the Laskar Jihad in Cyberspace," Australian Journal of Anthropology 15, no. 3 (2004): 267-285; Bonan Dolok Oktavianus Siagian and Arwin D.W. Sumari, "Radicalism Discourse Analysis on Online Sites in Indonesia," Jurnal Pertahanan 1, no. 2 (2015), 67; Jennifer Yang Hui,
} 
media, are used by the Islamist groups to spread religious radical ideologies and propagate their doctrines as well as to explore and recruit potential cadres, and even to voice jihad against the legitimate government. ${ }^{2}$ A number of Islamic organizations in Indonesia that are suspected of being radical ${ }^{3}$ such as Hizbut Tahrir Indonesia (HTI, the Indonesian Liberation Party), Front Pembela Islam (FPI, Islamic Defenders Front), Kesatuan Aksi Mahasiswa Muslim Indonesia (KAMMI, the Indonesian Muslim Student Action Unit), Jamaah Ansharud Daulah (JAD, the State Supporters Group), Harakah Tarbiyah (the Tarbiyah Movement), and the Salafi Jamaah, are also reportedly developing what is called "social media jihad" among young Muslims by utilizing a number of new media platforms. ${ }^{4}$ The use of the new media platforms as the strategy of spreading religious radical ideology has now taken place in a much more systematic, structured and goal-oriented way.

Primarily, new media platforms-especially social media-are currently widely used by hardline Islamic groups in Indonesia to communicate and spread ideological messages as well as to recruit and select new cadres of youths and university students. The choice to use social media makes sense since young people and students are the

"The Internet in Indonesia: Development and Impact of Radical Websites," Studies in Conflict and Terrorism 33, no. 2 (2010): 171-191; Nurdin, "Radicalism on World Wide Web and Propaganda Strategy," Al-Ulum 16, no. 2 (2016), 265.

2 Anne Aly et al., "Introduction to the Special Issue: Terrorist Online Propaganda and Radicalization," Studies in Conflict and Terrorism 40, no. 1 (2017): 1-9; Ali Fisher, "Swarmcast: How Jihadist Networks Maintain a Persistent Online Presence," Perspectives on Terrorism 9, no. 3 (2015); Jytte Klausen et al., "The YouTube Jihadists: A Social Network Analysis of Al-Muhajiroun's Propaganda Campaign," Perspectives on Terrorism 6, no. 1 (2012); Martin Rudner, "Electronic Jihad': The Internet as Al Qaeda's Catalyst for Global Terror," Studies in Conflict and Terrorism 40, no. 1 (2017): 10-23; Robin Thompson, "Radicalization and the Use of Social Media," Journal of Strategic Security 4, no. 4 (2011): 167-190.

3 Muhammad Wildan, "The Nature of Radical Islamic Groups in Solo," Journal of Indonesian Islam 7, no. 1 (2013): 49-70.

${ }^{4}$ Asep M. Iqbal, "Internet, Identity and Islamic Movements: The Case of Salafism in Indonesia," Islamika Indonesiana 1, no. 1 (2014), 81; Nafi Muthohirin, "Radikalisme Islam Dan Pergerakannya Di Media Sosial," Afkaruna 11, no. 2 (2015): 240-259; Mohamed Nawab Mohamed Osman, "Reviving the Caliphate in the Nusantara: Hizbut Tahrir Indonesia's Mobilization Strategy and Its Impact in Indonesia," Terrorism and Political Violence 22, no. 4 (2010): 601-622; Syamsul Rijal, "Crafting Hizbiyyin in Contemporary Indonesia: Da'wah and Recruitment of Hizbut Tahrir Indonesia in South Sulawesi," Journal of Indonesian Islam 5, no. 1 (2011): 130-152,. 
biggest users of social media in Indonesia today. A number of social media that are commonly exploited by radical Islamic groups in Indonesia include Facebook, Twitter, Instagram, Line, WhatsApp, and Telegram. Interestingly. Members then can duplicate these social media platforms for further campaign of their radical religious ideologies. The so-called "channelization strategy" in using social media is the key to the process of spreading ideology and recruitment of new cadres to radical Islamic groups in Indonesia today.

This article describes the attempt of radical-religious Islamist groups to develop a channelization strategy to recruit potential cadres who can be relied upon in the dissemination of Islamic ideology among Muslim students in Indonesia. This screening-like system is perceived as a channelization effort developed as a part of the recruitment method and an attempt to launch their messages and expand their propaganda to the younger people, particularly students. The data presented in this article is based on the result of field research carried out in seven public universities in Indonesia that have been suspected by BNPT (Badan Nasional Penanggulangan Terorisme, National Anti Terrorism Board) of being infiltrated by radical Islamic ideology: the University of Indonesia, Bogor Agricultural University, Bandung Institute of Technology, Diponegoro University, Airlangga University, the Ten November Institute of Technology, and Brawijaya University. ${ }^{5}$

The main question is: what and how new media channels and platforms have been used by the radical-religious groups in Indonesia to disseminate their ideology and to recruit new members? It is important to discuss this question further as what we have seen in the last five years that there have been indications of the increasing spread of radical ideology among Muslim students in Indonesia.

This study uses a mixed method, ${ }^{6}$ combining quantitative and qualitative kinds. The quantitative method is used for two purposes: first, to obtain an initial overview of the phenomenon of the channelization of radical ideology among Muslim university students in Indonesia, and second, to obtain general data about the process of channeling radical ideologies in the aforementioned seven universities.

\footnotetext{
5 See https://kabar24.bisnis.com/read/20180531/255/801534/daftar-7-kampus-topdi-indonesia-terpapar-radikalisme

${ }^{6}$ Max Weber, Edward A. Shils, and Henry A. Finch, The Methodology of the Social Sciences (New York: Free Press, 1997).
} 
However, samples in this study are taken purposively, with the aim to understand the processes and strategies for spreading religious radical ideology among Muslim university students in Indonesia.

The qualitative method is used to obtain in-depth data on the forms of radical ideological channelization practices among Muslim university students in Indonesia. Field research and data collection processes, both quantitatively and qualitatively, were carried out in the period of August-November 2018. The quantitative method is used to map the general conditions of the phenomenon of the spread of radical ideology among Muslim university students in Indonesia. There are in total 700 Muslim students as the respondents, with details of 100 Muslim students from each campus who have been exposed to radical ideology.

\section{Religion, Radicalism, and Media}

Since 2005, there has been a phenomenon in Indonesia that Greg Fealy referred to as "conservative turn" in the religious life of Indonesian Muslims. ${ }^{7}$ Referring to Fealy's terminology, a conservative turn is a phenomenon of the increasing interpretation of religious understanding that is timid, puritanical and intolerant. The popular images of Muslims in Indonesia, who were previously known as moderate, friendly, tolerant, and open, have turned to become conservative, closed, prejudiced, and radical. ${ }^{8}$ Even, two of the largest Islamic organizations in Indonesia: Nahdlatul Ulama (NU) and Muhammadiyah, now seem somewhat marginalized and face a decrease in popularity. ${ }^{9}$

\footnotetext{
7 Greg Fealey, "A Conservative Turn: Liberal Islamic Groups Have Prompted a Backlash," Inside Indonesia 87 (2006): 35-52; Kikue Hamayotsu, "Conservative Turn? Religion, State and Conflict in Indonesia," Pacific Affairs 87, no. 4 (2014).

8 Vedi R Hadiz, "Towards a Sociological Understanding of Islamic Radicalism in Indonesia," Journal of Contemporary Asia (2008): 37-41; Marteen van Bruinessen, What Happened to the Smiling Face of Indonesian Islam?: Muslim Intellectualism and the Conservative Turn in Post-Suharto Indonesia, 2011; Fealey, "A Conservative Turn,”; Hamayotsu, "Conservative Turn?"

9 Martin Van Bruinessen, "Genealogies of Islamic Radicalism in Post-Suharto Indonesia 1," South East Asia Research (2002): 117-154; Minako Sakai and Amelia Fauzia, "Islamic Orientations in Contemporary Indonesia : Islamism on the Rise?," Asian Ethnicity, no. November 2014 (2014): 37-41; Bruinessen, What Happened to the Smiling Face of Indonesian Islam?: Muslim Intellectualism and the Conservative Turn in PostSubarto Indonesia.
} 
The development of communication and information technology, ironically, does not change the reality of conservatism among the Muslim communities in Indonesia. Indeed, there is a strong connection between the growth in communication technologies and the phenomenon of a conservative turn in Indonesia and how the growth in technologies heavily influenced the rise of that phenomenon. The spread of a conservative and radical-religious ideology that was previously carried out offline (through traditional magazines, bulletins, leaflets) have now incorporated the use of new media (through various types of new media, especially social media). This shift is apparently in line with the increased use of new media by global radical-religious organizations all over the world. ${ }^{10}$

Since the late 1990s and early 2000s, a number of transnational terrorist organizations such as Al Qaeda and ISIS have used blogs, pages, forums and social media (Facebook, Twitter and YouTube) as the spearhead of their "media jihadi" to the world. ${ }^{11}$ Among the earliest attempts by Islamic radical groups to make use of the internet was Azzam.com, a page created by a Muslim student at Imperial College, London in 1997. Since then, this page has been copied and referred to as an example by other Islamic radical groups to encourage their followers to create or produce similar pages. ${ }^{12}$ The significant increase of Internet users becomes the main cause of the rapid shift in methods and strategies done by radical-religious organizations globally.

The use of new media as a strategy for spreading radical-religious ideology includes four aspects of interest, namely as a means of coordination between members, as a media tool for ideological propaganda, as a way to recruit new members and as a way to 'train' new members. ${ }^{13}$ As part of changes in the strategy of using the media more broadly, new media such as Facebook, Telegram, and YouTube

${ }^{10}$ John Curtis Amble, "Studies in Conflict \& Terrorism Combating Terrorism in the New Media Environment," Studies in Conflict \& Terrorism (2012): 37-41; Maura Conway, "Determining the Role of the Internet in Violent Extremism and Terrorism: Six Suggestions for Progressing Research," Studies in Conflict \& Terrorism (2016); Martin Rudner, “"Electronic Jihad': The Internet as Al-Qaeda 's Catalyst for Global Terror," Studies in Conflict \& Terrorism (2016).

${ }^{11}$ James P Farwell, “The Media Strategy of ISIS," Survival: Global Politics and Strategy 56, no. 6 (2014): 37-41.

12 Amble, "Studies in Conflict \& Terrorism Combating Terrorism in the New Media Environment."

13 Ibid.; Farwell, “The Media Strategy of ISIS." 
have succeeded in radically transforming the method of radicalreligious ideology propaganda. ${ }^{14}$

An interesting study by Bloom and Daymon ${ }^{15}$ proposes that the dissemination process through new media platforms does not occur in a single and integrated manner, clarifying that one-third of ISIS' propaganda and messages in social media consisted of a positive and constructive idea of the Islamic Caliphate. According to them, through social media, ISIS adopts a strategy to spread their propaganda by aiming their ideological messages at various groups. By producing different propaganda materials for a different audience, ISIS believes that audience may find their message useful and inspiring by each audience's level of faith and understanding about Islam. However, once audiences find themselves involved in the organization, a single doctrinal similarity about absolute loyalty to each of its members appears strong, and violence as a way to achieve the goal of the establishment of Islamic Caliphate tends to be enforced. ${ }^{16}$

A number of previous studies have discussed the crucial role of the new media as a means of spreading radical-religious ideology by emphasizing the types of new media along with itsadvantages in disseminating this radical-religious ideology. ${ }^{17}$ What seems to be inadequate from the previous studies is the assumption that users of new media tend to be passive, receiving any available information from those media platforms, no more than consuming radical-religious ideology. However, the facts have shown that there are a number of

\footnotetext{
${ }^{14}$ See Anne Aly, "Brothers, Believers, Brave Mujahideen : Focusing Attention on the Audience of Violent Jihadist Preachers," Studies in Conflict \& Terrorism (2016).; Andre, "Neojihadism' and YouTube: Patani Militant Propaganda Dissemination and Radicalization 'Neojihadism'," Asian Security (2012): 37-41; Rudner, “"Electronic Jihad': The Internet as Al-Qaeda 's Catalyst for Global Terror."

15 Mia Bloom and Chelsea Daymon, "Assessing the Future Threat: ISIS's Virtual Caliphate," Foreign Policy Research Institute (2018): 372-388.

${ }^{16}$ Ibid.

${ }^{17}$ Conway, "Determining the Role of the Internet"; Aly, "Brothers, Believers, Brave Mujahideen"; Andre, "Neojihadism' and YouTube"; Klausen, "Tweeting the Jihad: Social Media Networks of Western Foreign Fighters in Syria and Iraq," Studies in Conflict \& Terrorism (2015); Hara and Stevens, "Echo Chambers and Online Radicalism: Assessing the Internet's Complicity in Violent Extremism," Policy \& Internet 7, no. 4 (2015): 401-422; Hew Wai Weng, "The Art of Dakwah: Social Media, Visual Persuasion and the Islamist Propagation of Felix Siauw and the Islamist Propagation of Felix Siauw," Indonesia and the Malay World 46, 134 (2018): 61-79.
} 
new media users who actively disseminate, produce, and reproduce those radical messages through the cyberspace. In addition, previous studies have not yet discussed the patterns, strategies, and methods of using the new media to spread that radical-religious ideology. Moreover, there has not been any research and explanation on whether the process of disseminating radical-religious ideology in Indonesia takes place in a single and integrated manner or heterogeneous and diffused.

This study attempts to fill in the gap in the literature surrounding the issue of religion, radicalism and the use of media by proposing an argument that the dissemination process of radical religious ideology in the new media among Muslim students in Indonesia takes place systematically and in a structured way through a process which can be called 'channelization of ideology.'

\section{New Media and the Dissemination of Radicalism}

Several Islamic radical-religious organizations in Indonesia such as HTI, KAMMI, JAD, FPI, and small salaf and tarbiyah groups rely upon communication and information technology to spread their propaganda messages to students. They disseminate those messages through a wide variety of new media platforms such as blogs, vlogs, official organization pages, supporting pages, and numerous social media and messaging platforms (Facebook, Instagram, Telegram, Twitter, YouTube, WhatsApp, Line) (see Figure 1).

There are some benefits of using new media platforms as a means of spreading radical-religious ideology and propaganda messages among students in Indonesia. First, easily accessible through mobile phones and laptop with available Internet connection. Second, highly interactive, as students heavily rely on social media to interact with other people. Third, targeting the right consumers, as students spend huge amount of their time on social media. Fourth, relatively inexpensive, compared to other media such as magazines, brochures, leaflets or newspapers. Fifth, interlinked, allowing the spread of radical-religious ideology to take place more effectively and optimally. Sixth, easy to analyze, because, with online data available, analysis can be carried out to achieve the goal of disseminating radical-religious ideology more accurately. 
Rahma Sugihartati, Bagong Suyanto, and Medhy Aginta Hidayat

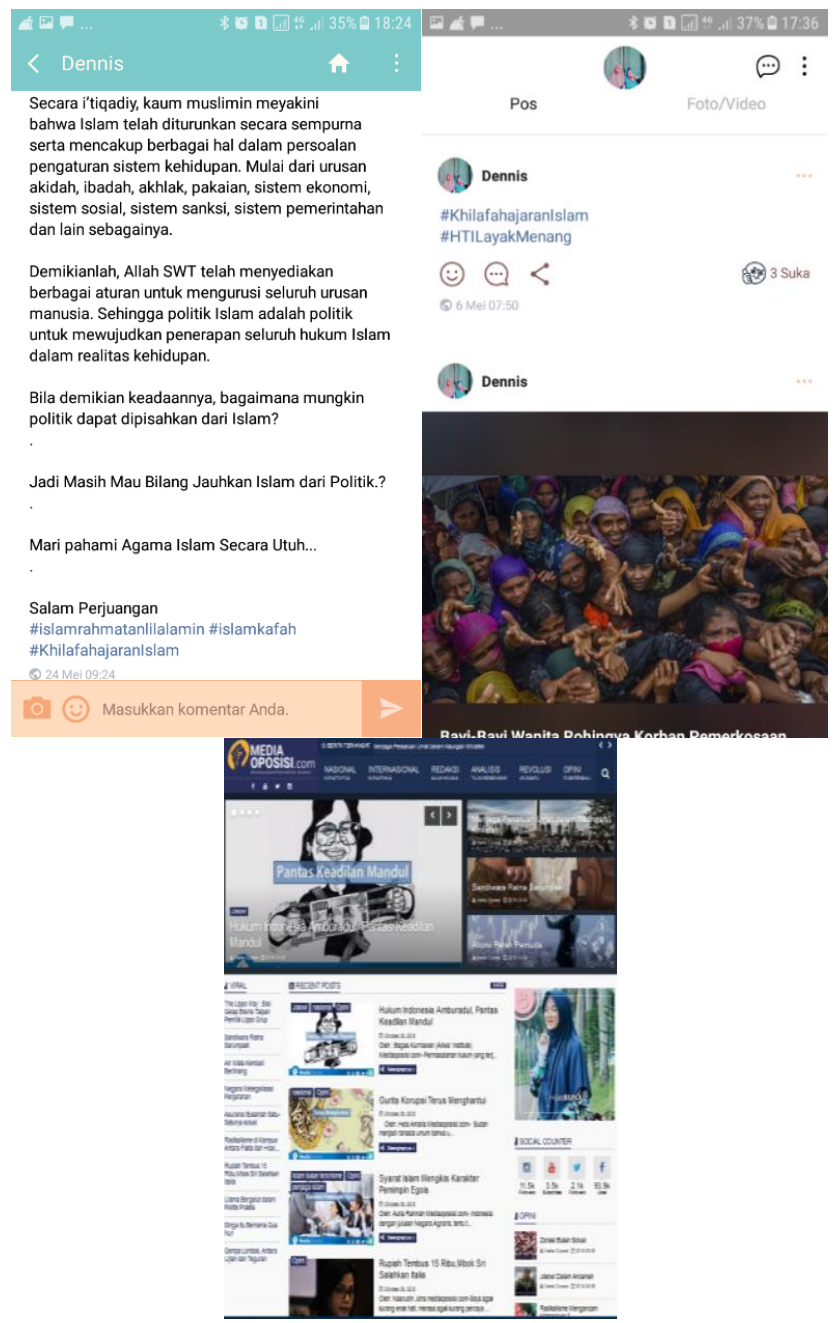

Figure 1. Examples of the Spread of Radical Ideology through New Media

A popular Muslim figure, notoriously known for transmitting radical Islamic ideology in Indonesia is Felix Siauw, whose belief and perception is associated with HTI. He relies on social media (Instagram, Twitter, and Facebook) to deliver religious messages targeting Muslim youth and students. ${ }^{18}$ A number of other ustadzs who

18 Weng, "The Art of Dakwah."

$316 \mid$\begin{tabular}{l|l} 
JOURNAL OF INDONESIAN ISLAM \\
VOLUME 14, NUMBER O2, DECEMBER 2020
\end{tabular} 
are associated with preaching radical Islamic ideology such as Khalid Basalamah, Riza Basalamah, Syafiq Reza, Subhan Bawazier, Salim Fillah, also utilize social media to spread their ideological narratives about the importance of shariah law, the total Islam, Islamic state, and Caliphate enforcement in Indonesia.

Table 1. Followers of Ustadz on Social Media

\begin{tabular}{lr}
\hline \multicolumn{1}{c}{ List of $\boldsymbol{U s t a d z}$} & Percentage of Followers \\
\hline Felix Siauw & $35,1 \%$ \\
Zakir Naik & $18,1 \%$ \\
Rizieq Shihab & $15,7 \%$ \\
Bachtiar Nasir & $2,6 \%$ \\
Abu Bakar Ba'asyir & $2,1 \%$ \\
Tengku Zulkarnain & $1,6 \%$ \\
Khalid Basalamah & $0,7 \%$ \\
Riza Basalamah & $0,7 \%$ \\
Syafiq Reza & $0,7 \%$ \\
Salim Fillah & $0,7 \%$ \\
Subhan Bawazier & $0,7 \%$ \\
Not following at all & $21 \%$ \\
\hline
\end{tabular}

Based on the quantitative study conducted, 700 students suggest that Siauw is one of the most popular Muslim public figures, who has a considerable number of students as his followers on social media (35.1\%) (see table 1). Zakir Naik, an Indian Islamic preacher, has become the second most popular Muslim figure on social media among Indonesia Muslim students (18.1\%). Other radical Muslim figures such as Rizieq Shihab (15.7\%), Bachtiar Nasir (2.6\%), Abu Bakar Ba'asyir (2.1\%) and Tengku Zulkarnain (1.6\%) are also popular among Muslim students in Indonesia and known to have a vast number of followers on social media. Dennis, a student of Airlangga University, explains the reason why he becomes a social media follower of Siauw:

"I followed Ustadz Siauw's Instagram account because I think he's a cool guy. I know he was previously a non-Muslim, and he is currently a mu'allaf (a person converted to Islam), so technically he's new to this whole Islam thing. But what amazes me is that he knows literally different things about Islam, even exceeding other Muslims who were born into a strict Islamic background. He can preach and educate other Muslims. So, I think he's great. His books are also great. Sometimes I like to repost his Facebook postings on my timeline. Learning about Islam could be from 
anywhere. Through social media, da'wah websites and accounts, and so much more. We can seek that knowledge easily and I could easily relate it to myself."

Siauw is an Indonesian Muslim preacher of Chinese descent and is known to be affiliated with the transnational Islamist movement, HTI $^{19}$ Siauw's method of preaching is popular among young people, especially students since he utilizes social media and visual aesthetics in the way he preaches, which attract more youth. With his popular method of preaching, Siauw has managed to gain considerable number of social media followers: four million on Facebook, two million on Twitter, one million on Instagram, and twenty thousand on YouTube. His da'wah approach is quite persuasive and compelling. However, at the same time, Siauw's da'wah style, contents and messages are deemed to be controversial as he has been accused of promoting transnational Caliphate and undermining Pancasila.

Table 2. Types of Social Media and the Dissemination of Radicalism

\begin{tabular}{lr}
\hline \multicolumn{1}{c}{ Types of Social Media } & Percentage of Users \\
\hline Instagram & $50,9 \%$ \\
WhatsApp & $22,3 \%$ \\
Twitter & $17,9 \%$ \\
Facebook & $5 \%$ \\
YouTube & $2,6 \%$ \\
Telegram & $1,3 \%$ \\
\hline
\end{tabular}

The use of new media, especially social media, as the primary platform for the dissemination of radical-religious ideology among Muslim students in Indonesia is in line with the global trend of shifting patterns and strategies for spreading radicalism. ${ }^{20}$ The new media is perceived as having advantages over traditional-conventional media, such as magazines, newspapers, television, and radio as a means of transmitting radical ideas in Indonesia. ${ }^{21}$

\footnotetext{
${ }^{19}$ Ibid.

20 Cristina Archetti, "Terrorism, Communication and New Media: Explaining Radicalization in the Digital Age," Perspectives on terrorism 9, no. 1 (2015): 49-59; Anne Aly et al., "Introduction to the Special Issu: Terrorist Online Propaganda and Radicalization," Studies in Conflict \& Terrorism (2016); Amble, "Combating Terrorism in the New Media Environment"; Conway, "Determining the Role of the Internet"; Aly, "Brothers, Believers, Brave Mujahideen."

${ }^{21}$ Martin Van Bruinessen, Contemporary Developments in Indonesian Islam: Explaining the “Conservative Turn" (Singapore: ISEAS Publishing, 2013).
} 
Social media plays a crucial role in the process of spreading radicalism to Muslim students in Indonesia (see Table 2). Among the various forms of social media available, Instagram (50.9\%), WhatsApp $(22.3 \%)$ and Twitter $(17.9 \%)$ rank highest as the new media most widely used by students in accessing radical contents. For the following rank, there are Facebook, YouTube, and Telegram used as a media for the dissemination of radicalism to Muslim students in Indonesia.

Instagram in particular, as suggested above, is the most popular social media platform among Muslim students in Indonesia who have been actively joining radical-religious groups on social media $(9.4 \%)$ (see Table 3). Another social media platform that is widely used to access and obtain contents about radicalism of Islam are Line (7.3\%), Facebook (5.4\%), Chatroom (4.1\%), Snapchat (1.4\%) and Twitter $(0.4 \%)$.

Table 3. Signing Up \& Joining in Radical Religious Groups on Social Media

\begin{tabular}{lrrr}
\hline Social Media & Actively Use & Non-actively Use & Never Use \\
\hline Instagram & $9,4 \%$ & $13,3 \%$ & $77,3 \%$ \\
Line & $7,3 \%$ & $3,3 \%$ & $89,4 \%$ \\
Facebook & $5,4 \%$ & $17,1 \%$ & $77,5 \%$ \\
Chatroom & $4,1 \%$ & $2,9 \%$ & $93 \%$ \\
Snapchat & $1.4 \%$ & $1,4 \%$ & $97,2 \%$ \\
Twitter & $0,4 \%$ & $2,1 \%$ & $97,5 \%$ \\
\hline
\end{tabular}

As part of the net generation, or often referred to as digital natives, students have grown up using technology and thus fully versed in the world of bits and bytes. In comparison, the previous generation (baby boomers), who are still having a hard time adjusting to modern technology, rely more on face-to-face interactions and would prefer to access information through the print media.

\section{Channelization and the Proliferation of Radicalism}

Through the activities of study and lectures, students who become members of radical Islamic organizations have been socialized to believe and support the Islamic Caliphate. Not only through face-toface interactions, the strategies of disseminating radical-religious ideology and the process of recruiting new members also rely heavily on social media through channelization strategies. Channelization refers to a strategy of creating and directing channels in a structured manner to spread ideology and propaganda messages through various 
new media platforms, such as blogs, vlogs, organization websites and social media.

Rina, a student of Bogor Agricultural University who is also a respondent of this research, explains how the channelization of information has been already enforced since the beginning as an effort to introduce radical-religious organizations in her university:

"So, it's like we all have to go through this filtering system. We are not allowed to ask too many questions. And of course, when we first join in, we must do as we are told. Even when it comes to the reading materials. We couldn't just read whatever we want. Like me for example, I just joined in, so I had to read these books meant for beginners only. I was not allowed to read books with more advanced materials. So, what we can read is really limited and structured. Also, for websites, we are not allowed to read from whatever sources we can find."

Syam, another student of Airlangga University, mentions how the organizations are limiting materials they could consume:

"Once we join in the Qur'anic studies sessions, we are not allowed to access or read information from whichever source we can find. I remember one of the girls from my Islamic group said that the ustadz had been telling them the danger of accessing information from the Internet. We have to be highly selective and protective of ourselves from those inappropriate contents. They also gave us some guidance to which sites are appropriate."

The channelization process of spreading radicalism in Indonesia takes place through three channels: open-public channel (K-1), restricted-public channel (K-2), and private channel (K-3) (see Table 4). Open-public channel (K-1) refers to the early and initial channel for the dissemination of radical-religious ideology and the spread of Islamic propaganda. It is carried out through popular Islamic social media websites and social media accounts of Islamic public figures who provide religious information affiliated with several religious organizations in Indonesia.

The first channel is effective in spreading the message of Islam. Its nature is meant to deliver Islamic contents in a more interactive and efficient way, and to increase the scalability of reach among Muslim students. Briefly, this first channel is usually similar to other da'wab sites or social media accounts with its contents and approach tending 
to be neutral, engaging, and not explicitly displaying the attributes of radical-religious organizations.

Table 4. Channelization Strategy to Disseminate Radical Ideology

\begin{tabular}{|c|c|c|c|c|}
\hline Channel & Objective & Characteristics & Role & Examples \\
\hline K-1 & $\begin{array}{l}\text { To } \\
\text { dissemi- } \\
\text { nate } \\
\text { general } \\
\text { informa- } \\
\text { tion and } \\
\text { Islamic } \\
\text { shari'ah }\end{array}$ & $\begin{array}{l}\text { Mainstream, } \\
\text { open, public, } \\
\text { popular }\end{array}$ & $\begin{array}{l}\text { The } \\
\text { consumer of } \\
\text { media } \\
\text { content and } \\
\text { information }\end{array}$ & $\begin{array}{l}\text { KonsultasiSyariah.com; } \\
\text { ParentingNaba- } \\
\text { wiyah.com; } \\
\text { Muslim.or.id; } \\
\text { MuslimAfiyah.com. } \\
\text { @muslimahID; } \\
\text { @fiqihwanita; } \\
\text { @hawariyyun; } \\
\text { @muzammilhb; } \\
\text { @ariekuntung; } \\
\text { @teukuwisnu; } \\
\text { Muslimah YouTube } \\
\text { channel; } \\
\text { Media Center (MMC); } \\
\text { Yuk Ngaji. }\end{array}$ \\
\hline $\mathrm{K}-2$ & $\begin{array}{l}\text { Dissemi- } \\
\text { nate in- } \\
\text { depth } \\
\text { informa- } \\
\text { tion about } \\
\text { the } \\
\text { ideology } \\
\text { of radical- } \\
\text { religious } \\
\text { organiza- } \\
\text { tions }\end{array}$ & $\begin{array}{l}\text { Special, } \\
\text { public, limited, } \\
\text { closed, deep }\end{array}$ & $\begin{array}{l}\text { Consumer } \\
\text { and } \\
\text { producer of } \\
\text { media } \\
\text { content and } \\
\text { information }\end{array}$ & $\begin{array}{l}\text { HTI website, FPI, } \\
\text { KAMMI, } \\
\text { MediaUmat.com, } \\
\text { Arrahmah.com, } \\
\text { MediaOposisi.com, } \\
\text { VOAIslam.com, Twitter } \\
\text { accounts, HTI, FPI, } \\
\text { @indonesiabertauhid, } \\
\text { @mediaumat. }\end{array}$ \\
\hline K-3 & $\begin{array}{l}\text { Selection } \\
\text { new } \\
\text { members } \\
\text { to join the } \\
\text { organiza- } \\
\text { tions }\end{array}$ & $\begin{array}{l}\text { Private, } \\
\text { exclusive, } \\
\text { limited }\end{array}$ & $\begin{array}{l}\text { Consumer } \\
\text { and produ- } \\
\text { cer of media } \\
\text { content and } \\
\text { information }\end{array}$ & $\begin{array}{l}\text { ITS's WhatsApp group } \\
\text { chat, UI's student } \\
\text { telegram group }\end{array}$ \\
\hline
\end{tabular}

Another typical feature of the dissemination of radicalism through the first channel is the presence of a Q\&A section that allows students to ask, and share any information related to general religious issues. Further, in the same section, students are provided with links to the official pages of organizations and websites or social media to discuss 
further those issues. Students who are given access to the first channel of dissemination strategy mostly only take part as information consumers, instead of producers or a combination of both. The excerpt from Dila, a student of Bogor Agricultural University, below is so illustrative:

"I think I tend to access information through websites because I feel like Qur'anic study groups are not enough. And I also don't have time to go. So, websites are my go-to for more information. Some of the websites I like are konsultasiSyariah.com or parentingNabawiyah.com. I also follow some official da'wa accounts at Line."

Azhar, a student of Brawijaya University, suggests a similar argument:

"Those ustad₹s on social media are pretty amazing to be honest and plus I don't feel the need to go to the Qur'anic study group anymore. Those contents on social media has provided me with plenty of information. My friends and I, we prefer to watch videos on YouTube rather than going to the study group. It's much more flexible I guess".

The main purpose of the first channel is to provide students who have recently joined or who are eager to learn more general information about Islam. Examples of media platforms of the first channel are ConsultationSyariah.com, ParentingNabawiyah.com, Muslim.or.id, MuslimAfiyah.com, while those of Instagram accounts include@muslimahID,@fiqihwanita, Instagram accounts of Islamic public figures such as@hawariyyun,@muzammilhb, @ariekuntung, @ teukuwisnu, just as those of YouTube channels are Muslimah Media Center (MMC) and Yuk Ngaji, or Teleskrin.

Restricted-public channel (K-2) refers to the dissemination of radicalism carried out through either the official websites or organizations, or other websites affiliated with radical-religious organizations or official social media sites that provide further information on radical-religious organizations. In contrast to the first channel, media platforms in the second channel feature appear to have less neutral contents and approach and tend to provide more specific information about the ideology of those radical-religious organizations.

Most of the students who access media contents within the second channel are not typical newcomers. However, those students are indeed already curious and eager to learn more about the ideology and 
significance of certain radical-religious organizations. Within this channel, students do not only take part as consumers of information, but also play a role as producers of contents by disseminating information, posting memes, or forming social media groups. A number of religious public figures who are relatively popular among students within the second channel are Siauw, Khalid Basalamah, Riza Basalamah, Reza, Bawazier, and Fillah. Most media platforms in the second channel tend to administer exclusivity -providing closed social media groups for students who are genuinely interested in learning more about those radical-religious organizations.

The purpose of the second channel is to provide more specific and in-depth information about the ideology and perception of certain radical-religious organizations. Examples of second channel media platforms are the official website of organizations such as HTI, FPI, KAMMI, Gema Pembebasan IPB, or the public pages affiliated with other radical-religious organizations such as MediaUmat.com, EraMuslim .com, Rumaysho.com DakwahMedia.net, Arrahmah.com, NahiMunkar.com, MediaOposisi.com, Hidayatullah.com, VOAIslam.com, WA group and Line TarbiyahSunnah, the official Twitter account of HTI, FPI or Instagram account including @indonesiabertauhid, @mediaumat,@bkimipb, or @mercusuar_umat. Mutiara, a student of Bogor Agricultural University, mentions:

"I very much prefer browsing through information online. Usually through WhatsApp or Line group, or straight to their official websites. Because on social media, it's likely that we'll encounter hoax and other misleading information. My ustadz also reminds us of reading materials through sites that have been approved by the organization. I don't think we're really allowed to access other sites. He said it's bid'ah [unwarranted religious innovation]. So, I think it's better just to access those information from the approved websites or even ask any experts straight away on the chat groups. If you've heard of "Tarbiyah Sunnah," or websites called Rumaysho.com, DahwahMedia.net.? On those sites, we can also do an online consultation since there's this online Q\&A feature that site provides us. It's simply making things so much easier."

Through the Q\&A feature, those organizations are then able to observe and discover curious students who potentially make the 
perfect candidate to join private and close groups within the third channel.

Private channel (or K-3) is the channel for the dissemination of radical-religious ideology that is carried out through closed social media groups, especially WhatsApp or Line groups or telegram. Within the same channel, the process of recruiting new members also occurs. In contrast to media platforms within the first and second channel, the third channel does not incorporate various media platforms, as they tend to be more limited and disclosed. Through closed and private social media groups, the process of channelization and spreading radical-religious ideologies can occur more effectively. Below are excerpts from students who are members of closed social media groups:

"We have this WhatsApp group and only a specific number of people can join in. We also have a more public Qur'anic study group itself though but not everyone is a member of HTI. But this group I mentioned before, we coordinate, and we run things together. Each has their role. So, in this group, we have darisah, musrifah and other admin people" (Rin, a student of the Ten November Institute of Technology).

"I'm a member of this telegram group because my friend gave me an exclusive group invite. Without the invitation, I wouldn't be able to join in. This is a very private closed up, only for UI" Jani, a student of the University of Indonesia).

The closed social media groups in the third channel consist of students who have gone through the process of 'filtering' within the first and second channels. Those who are deemed suitable to join the radical-religious organizations should have certain characteristics. Within this closed social media groups, students who had been exposed to propaganda messages and had embraced the radical religious ideology are encouraged to exchange and discuss information with other members in a secretive manner. The processes of exchanging information can lead to the dissemination of radicalreligious ideology that is solid and structured. It is also common that most students who have access to media platforms in the third channel produce and spread propaganda messages and radical-religious ideology through their creation of meme.

The aim of the third channel in addition to screening new cadres and recruiting new members, it is also used as a channel to provide 
more in-depth information about the ideology of radical-religious organizations. Examples of media platforms within the third channel are the closed telegram group of the JAD which consist of students of the University of Indonesia or members of closed WhatsApp group of students oft the Ten November Institute of Technologywho are associated with HTI organization. Because it is exclusive, closed, and private, within the third channel, not everyone can participate in the selected media platforms. Only those who had gone through the screening processes as members can join in.

The strategy of developing the channelization of ideology aims to use new media platforms to describe the Islamic State as a land that is full of happiness to recruit supporters. Within the third channel that is more, private, and personal, these organizations believe that the strategy is more effective in persuading the younger people. By implementing the channelization strategy to students, the primary goal is to enforce a more militant and radical belief to young people. Hence, students have become prosumer of information who actively consume while producing radical contents as part of the act of Jihad that they believe is appropriate and justified.

\section{The Channelization Strategy Model of Radicalism through New Media}

The dissemination of radical-religious ideology among Muslim students in Indonesia via new media is a logical consequence of the change in the character of society, from modern society to postmodern internet-based and AI-based society that is dominated by consumption activities emphasizing effectiveness and efficiency. ${ }^{22}$ This postmodern society is also more democratic and open, and does not acknowledge absolute power. In this context, the high penetration of internet and social media in Indonesia is the focus. The vast number of social media users in Indonesia, especially from young people and students, is targeted by radical-religious organizations to distribute their ideology and influence.

In general, the process of spreading radical-religious ideology via new media is an extension of the same process using traditionalconventional media. This is in line with the argument of Marshall McLuhan, which has reminded that technological developments will be

22 Kikue Hamayotsu, "Beyond Faith and Identity: Mobilizing Islamic Youth in a Democratic Indonesia," The Pacific Review 24, no. 2 (2011): 225-247. 
a solution to human physical limitations. ${ }^{23}$ The communication channel in the dissemination of radical-religious ideologies has changed from traditional communication channels (television, radio, newspapers, magazines, brochures) to new media (websites, blogs, video blogs, and social media). The new media now play an important role as the primary communication channel used by producers of radical-religious ideologies to expand their influence on Muslim students in Indonesia. Social media are more effective and massive as an instrument for disseminating radical ideas. The dissemination using social media is also faster as well as more interactive and widespread.

The channelization strategy in the process of transmitting radicalism, especially through social media, can further be a rationaltechnological effort to filter and attract followers who have the same level of understanding. On social media, the similarity of individual attributes, such as social, cultural, educational, religious, and ideological backgrounds, plays an important role in the process of social interaction. A number of studies on the phenomenon of 'homophily' has indicated that individuals with relatively similar attributes and characteristics tend to interact more easily with one another and share the same information. ${ }^{24}$ Social media users tend to be more receptive to information that is the same or by their beliefs, and more likely to join groups of which members have similar attributes or views as they do. ${ }^{25}$

The similarity of individual attributes of social media users is further affirmed by what Eli Pariser calls the "filter bubble effect". ${ }^{26}$ Filter bubbles are artificial realities as a result of algorithms of search engine and social media platforms where internet users will tend to receive different information according to their profile, their location, their behavior in using the internet, and even according to their

${ }^{23}$ McLuhan M., Understanding Media: The Extension of Man (New York: McGraw Hill, 1964).

${ }^{24}$ Miller Mcpherson, Lynn Smith-lovin, and James M Cook, "Birds of a Feather: Homophily in Social Networks," Annual Review of Sociology 27 (2001): 415-444; Munmun De Choudhury, Hari Sundaram, and Anjati John, Birds of a Feather: Does User Homophily Impact Information Diffusion in Social Media?, 2010.

25 Choudhury, Sundaram, and John, Birds of a Feather: Does User Homophily Impact Information Diffusion in Social Media?".

${ }^{26}$ Eli Pariser, The Filter Bubble: What the Internet Is Hiding from You (New York: Penguin Pers, 2011). 
browsing history. In the reality of this filter bubble, internet users with similar profile preferences will tend to receive the same information. On the contrary, internet users with different profile preferences will receive different information. As a result, the digital world has created bubbles that cause internet users to live by their profile, and their profile alone.

On the one hand, because of bubble filters, internet users, especially social media ones, with the same attributes and profiles are more likely to receive the same information and join the same group. ${ }^{27}$ On the other hand, people who are stuck in the bubble filter will find it difficult to receive information from social media users who have different individual attributes and profiles from them. Consequently, those who live in the reality of bubble filters will tend to reinforce any message or information received from the group. This is a phenomenon that is often referred to by media communication experts as the echo chamber effect. ${ }^{28}$

The channelization strategy of radical-religious ideologies via new media is a networking process to find "birds of a feather" who are ideologically ready to fight for radical-religious organizations. In this context, it is interesting to take a look at the findings of Arquilla and Ronfeldt, as cited by Jackson, ${ }^{29}$ which have presented three structures of organizational communication networks in terrorist groups: chain network, where organizational units are connected sequentially in a row; bub and spoke network, where links to all units come out of one node; and all-channel network, where all units are connected to all others in the organization.

Referring to the framework of network structure below (Figure 2), this study finds that channelization strategy of radical-religious ideologies via new media is more closely related to all-channel network than to chain network and bub and spoke network. More clearly, the actors of spreading radicalism in the channelization model have non-

\footnotetext{
27 Mcpherson, Smith-lovin, and Cook, "Birds of a Feather"; Choudhury, Sundaram, and John, Birds of a Feather.

${ }^{28}$ Cass Sunstein, Republic.Com 2.0 (Princeton: Princeton University Press, 2009); Seth Flaxman, Sharad Goel, and Justin Rao, "Filter Bubbles, Echo Chambers, and Online News Consumption,” Public Opinion Quarterly 80, no. S.1 (2016): 24-29.

${ }^{29}$ Brian A Jackson, "Groups, Networks, or Movements: A Command-and- ControlDriven Approach to Classifying Terrorist Organizations and Its Application to Al Qaeda," Studies in Conflict \& Terrorism (2006): 37-41.
} 
hierarchical characters that are connected to each other, even though the communication pattern is not fully democratic.

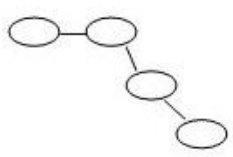

Chain Model

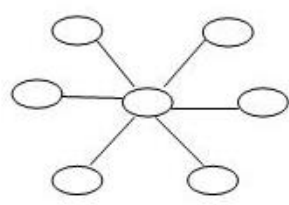

Hub and Spoke Model

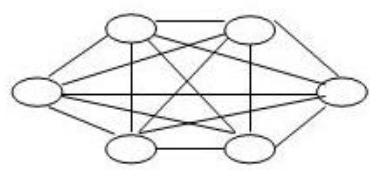

All-Channel Model

Figure 2. Communication Network Structure of Terrorist Organization

Furthermore, the channelization strategy model of radical ideologies via new media is also somewhat different from the network structure of Arquilla and Ronfeldt which tends to ignore selection processes of individuals who support radical ideology through different criteria and types of new media. Referring to the model found in this study, the process of disseminating radical-religious ideologies occurred through a mechanism of "spreading and filtering", which aims to select and recruit new members, as well as to disseminate ideological teachings. Channelization of ideology which follows three stages - the open-public channel, the restricted-public channel, and the private channel-ultimately aims to attract new members to radicalreligious organizations that have the same ideological political view.

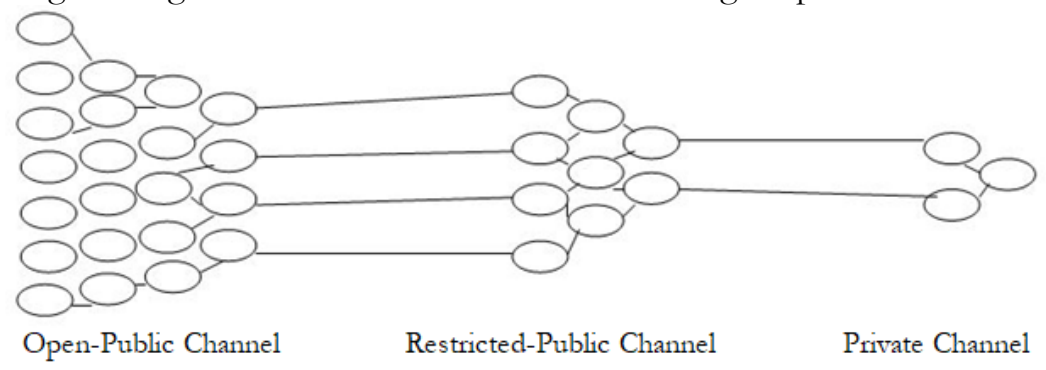

Figure 3. Ideology Channelization Model via New Media

The channelization strategy of radical ideologies developed by radical-religious organizations to attract new cadres can be analogous to "drainage" channel that gets narrower and directs the flow of information to the desired point (Figure 3). On the first channel, that is open-public channel, certain new public media that are popular and open such as blogs, video blogs, websites, and social media such as Facebook, Twitter, or Instagram, are used to disseminate ideological 
messages to the broader audience. Consumers of the information on the first channel level are not restricted, meaning that the information can be accessed by anyone.

On the restricted-public channel, new media used are fewer and the access is limited to their users. For example, Facebook groups or group conversation in Instagram are intentionally set as private groups. The consumer of information on this channel is limited and the information can only be accessed by those who have been approved to join the channel. On the private channel, the selection process is more stringent and closed. The types of social media that are widely used on this channel include Line, WhatsApp, and Telegram. Only those who want to become cadres of radical-religious organizations will receive information in private.

In general, the channelization strategy of radical-religious ideologies is almost the same as the strategy implemented by several traditional Islamic organizations in Indonesia, such as NU and Muhammadiyah, to instill certain religious and ideological teachings by providing channels for early childhood education and higher education. However, a fundamental difference can be seen in the use of new media as a means of ideology dissemination and the goal of the channelization process. The channelization strategy of traditional Islamic education in Indonesia does not relatively utilize new media as the primary media for the spread of their teachings. In addition, channelization of traditional Islamic education in Indonesia does not have the goal of recruiting new cadres. Religious understanding taught in traditional Islamic educational institutions does not restrain their students from believing their respective religious ideologies.

On the contrary, ideology channelization strategy of radical and transnational Islamic organizations in Indonesia such as HTI, KAMMI, JAD, Gema Pembebasan IPB, FPI, and other small groups of salafist and tarbiyah, purposely employs new media as the spearhead in distributing their ideology. Furthermore, this channelization strategy aims to attract new cadres.

\section{Conclusion}

The dissemination of radical-religious ideologies among Muslim students in Indonesia via new media occurs systematically and structurally. New media used in the dissemination of radicalism are blogs, pages, video blogs, forums, and social media. The distribution of radicalism among Muslim students in Indonesia employs 
channelization strategy, which is a technique of making channels for structurally disseminating information and ideological teachings of radical-religious organizations via blogs, video blogs, pages, forums, and social media. Channelization may follow three stages, namely open-public channel (K-1), restricted-public channel (K-2), and private channel (K-3).

This channelization is intentionally carried out and developed by radical groups to facilitate the process of transmitting radicalism through communication and coordination among members of radicalreligious organizations, and to recruit new cadres to their organizations. In contrast to the approach model that emphasizes the importance of widespread dissemination of ideology, ideology channelization via new media is consciously developed to deepen the beliefs of recruited cadres further so that they become more militant and radical and are always willing to defend radical ideology they have faith in. Not only expected to become passive consumers who regularly read various information on websites of organizations, students who have been indoctrinated by radicalism, and even involved in radical movements, are also expected to become prosumers who actively produce and recirculate messages of radicalism to other students and broader circles. []

\section{References}

Aly, Anne. "Brothers, Believers, Brave Mujahideen: Focusing Attention on the Audience of Violent Jihadist Preachers." Studies in Conflict \& Terrorism (2016).

Aly, Anne, Stuart Macdonald, Lee Jarvis, and Thomas M. Chen. "Introduction to the Special Issue: Terrorist Online Propaganda and Radicalization." Studies in Conflict and Terrorism 40, no. 1 (2017): 1-9.

Aly, Anne, Stuart Macdonald, Lee Jarvis, and Thomas M Chen. "Introduction to the Special Issue : Terrorist Online Propaganda and Radicalization." Studies in Conflict \& Terrorism (2016).

Amble, John Curtis. "Studies in Conflict \& Terrorism Combating Terrorism in the New Media Environment." Studies in Conflict \& Terrorism, (2012): 37-41.

Andre, Virginie. “'Neojihadism' and YouTube: Patani Militant 
Propaganda Dissemination and Radicalization 'Neojihadism' and YouTube: Patani Militant." Asian Security (2012): 37-41.

Archetti, Cristina. "Terrorism, Communication and New Media: Explaining Radicalization in the Digital Age." Perspectives on terrorism 9, no. 1 (2015): 49-59.

Bloom, Mia, and Chelsea Daymon. "Assessing the Future Threat: ISIS's Virtual Caliphate." Foreign Policy Research Institute Summer 201, no. April (2018): 372-388.

Bräuchler, Birgit. "Islamic Radicalism Online: The Moluccan Mission of the Laskar Jihad in Cyberspace." Australian Journal of Anthropology 15, no. 3 (2004): 267-285.

Bruinessen, Marteen van. What Happened to the Smiling Face of Indonesian Islam?: Muslim Intellectualism and the Conservative Turn in Post-Subarto Indonesia, 2011.

Bruinessen, Martin Van. Contemporary Developments in Indonesian Islam: Explaining the "Conservative Turn." Singapore: ISEAS Publishing, 2013.

- "Genealogies of Islamic Radicalism in Post-Suharto Indonesia 1." South East Asia Research, no. October 2001 (2002): 117-154.

Choudhury, Munmun De, Hari Sundaram, and Anjati John. Birds of a Feather": Does User Homophily Impact Information Diffusion in Social Media?", 2010.

Conway, Maura. "Determining the Role of the Internet in Violent Extremism and Terrorism: Six Suggestions for Progressing Research." Studies in Conflict \& Terrorism (2016).

Farwell, James P. “The Media Strategy of ISIS." Survival: Global Politics and Strategy 56, no. 6 (2014): 37-41.

Fealey, Greg. "A Conservative Turn: Liberal Islamic Groups Have Prompted a Backlash.” Inside Indonesia 87 (2006): 35-52.

Fisher, Ali. "Swarmcast: How Jihadist Networks Maintain a Persistent Online Presence." Perspectives on Terrorism 9, no. 3 (2015).

Flaxman, Seth, Sharad Goel, and Justin Rao. "Filter Bubbles, Echo Chambers, and Online News Consumption." Public Opinion 
Quarterly 80, no. S.1 (2016): 24-29.

Hadiz, Vedi R. "Towards a Sociological Understanding of Islamic Radicalism in Indonesia Towards a Sociological Understanding of Islamic Radicalism in Indonesia." Journal of Contemporary Asia (2008): 37-41.

Hamayotsu, Kikue. "Beyond Faith and Identity: Mobilizing Islamic Youth in a Democratic Indonesia." The Pacific Review 24, no. 2 (2011): 225-247.

-. "Conservative Turn? Religion, State and Conflict in Indonesia." Pacific Affairs 87, no. 4 (2014).

Hara, Kieron O, and David Stevens. "Echo Chambers and Online Radicalism: Assessing the Internet's Complicity in Violent Extremism." Policy \& Internet 7, no. 4 (2015): 401-422.

Hui, Jennifer Yang. "The Internet in Indonesia: Development and Impact of Radical Websites." Studies in Conflict and Terrorism 33, no. 2 (2010): 171-191.

Iqbal, Asep M. "Internet, Identity and Islamic Movements: The Case of Salafism in Indonesia." Islamika Indonesiana 1, no. 1 (2014): 81.

Jackson, Brian A. "Studies in Conflict \& Terrorism Groups, Networks, or Movements : A Command-and- Control-Driven Approach to Classifying Terrorist Organizations and Its Application to Al Qaeda A Command-and-Control-Driven Approach to Classifying Terrorist Organizations A." Studies in Conflict \& Terrorism (2006): 37-41.

Klausen, Jytte. "Studies in Conflict \& Terrorism Tweeting the Jihad: Social Media Networks of Western Foreign Fighters in Syria and Iraq Tweeting the Jihad: Social Media Networks of Western Foreign Fighters in Syria and Iraq." Studies in Conflict \& Terrorism (2015).

Klausen, Jytte, Eliane Tschaen Barbieri, Aaron Reichlin-Melnick, and Aaron Y. Zelin. "The YouTube Jihadists: A Social Network Analysis of Al-Muhajiroun's Propaganda Campaign.” Perspectives on Terrorism 6, no. 1 (2012).

McLuhan M. Understanding Media: The Extension of Man. New York: 
McGraw Hill, 1964.

Mcpherson, Miller, Lynn Smith-lovin, and James M Cook. "Birds of a Feather: Homophily in Social Networks." Annual Review of Sociology 27 (2001): 415-444.

Muthohirin, Nafi. "Radikalisme Islam dan Pergerakannya di Media Sosial." Afkaruna 11, no. 2 (2015): 240-259.

Nurdin, Nurdin. "Radicalism on World Wide Web and Propaganda Strategy." Al-Ulum 16, no. 2 (2016): 265.

Osman, Mohamed Nawab Mohamed. "Reviving the Caliphate in the Nusantara: Hizbut Tahrir Indonesia's Mobilization Strategy and Its Impact in Indonesia." Terrorism and Political Violence 22, no. 4 (2010): 601-622.

Pariser, Eli. The Filter Bubble: What the Internet Is Hiding from You. New York: Penguin Pers, 2011.

Rijal, Syamsul. "Crafting Hizbiyyin in Contemporary Indonesia: Da'wah and Recruitment of Hizbut Tahrir Indonesia in South Sulawesi." Journal of Indonesian Islam 5, no. 1 (June 1, 2011): 130152.

Rudner, Martin. "Electronic Jihad': The Internet as Al-Qaeda's Catalyst for Global Terror." Studies in Conflict \& Terrorism 0731, no. February (2016).

—. "Electronic Jihad': The Internet as Al Qaeda's Catalyst for Global Terror." Studies in Conflict and Terrorism 40, no. 1 (2017): 10-23.

Sakai, Minako, and Amelia Fauzia. "Islamic Orientations in Contemporary Indonesia: Islamism on the Rise?" Asian Ethnicity (2014): 37-41.

Siagian, Bonan Dolok Oktavianus, and Arwin D.W. Sumari. "Radicalism Discourse Analysis on Online Sites in Indonesia." Jurnal Pertahanan 1, no. 2 (2015): 67.

Sunstein, Cass. Republic.Com 2.0. Princeton: Princeton University Press, 2009.

Thompson, Robin. "Radicalization and the Use of Social Media." 
Rahma Sugihartati, Bagong Suyanto, and Medhy Aginta Hidayat

Journal of Strategic Security 4, no. 4 (2011): 167-190.

Weber, Max, Edward A. Shils, and Henry A. Finch. The Methodology of the Social Sciences. New York: Free Press, 1997.

Weng, Hew Wai. "The Art of Dakwah: Social Media, Visual Persuasion and the Islamist Propagation of Felix Siauw and the Islamist Propagation of Felix Siauw." Indonesia and the Malay World (2018).

Wildan, Muhammad. "The Nature of Radical Islamic Groups in Solo." Journal of Indonesian Islam 7, no. 1 (2013): 49-70. 